\title{
The Impact of Service Quality on Customer Satisfaction, Customer Loyalty and Brand Image: Evidence from Hotel Industry of Pakistan
}

\author{
Hamad Saleem, Naintara Sarfraz Raja \\ Foundation University Islamabad, (Corresponding author) \\ Assistant professor Department of Business \& Economics, foundation university Islamabad
}

\begin{abstract}
This study intent to investigate the impact of service quality on consumer satisfaction customer loyalty and brand image. The primary data was collected from 5 and 8 star hotels of Pakistan. The response rate was $86 \%$. Structural equation modeling (SEM) technique was used to analyze the data. The findings suggested that high quality of services boost up the customer satisfaction and then afterward this satisfaction will strengthen the customer loyalty, our results also matched with Brodie et al., (2009). Last but not the least strong customer loyalty directly related to strong brand image.

Keywords: Service quality, Brand image, Customer loyalty, SEM, Customer satisfaction.
\end{abstract}

\section{Introduction}

In this cut throttle competition every business is striving to attain edge over the other. For this reason they continuously are struggling to maintain their optimum position in the market. From the previous some decades, service quality and customer satisfaction considered as most important area of interest for academia and practitioners. But now a day's most of the people are focused to build up the customer loyalty and strong brand image between the customers and they will have significant impact on business recital and buyerdeeds. According to Gundersen et al., (1996) service quality leads to higher profitability. Hotel industry has become the most recognized industry all around the globe. Services of hotel industry include restaurants, rooms, health clubs are no longer considered as extravagance facilities. Among many people these services are the basic element of lifestyle. From the last two decades the hotel industry services have changed dramatically from traditional to current conditions. Supply of and demand for hotel industry services have boost up the growth for travelers, and competition goes in tensed in this market. Now a day's hotel organization is going through the greatest challenge that is ever growing volume and rapidity of competition.

Hotel industry managers consider that business can make their profits by satisfying customers. Most of the empirical evidence showed that only customer satisfaction does not guarantee you that satisfied customer will retained with you or will avail your services again. It is only the buyer loyalty that is significantly vitalthan customer satisfaction for business success. Whereas the business image is also an imperative consideration that may be optimistically or negatively influenced the marketing activities. Zeithaml and Bitner (1996) explained brand image, the ability to persuade the customer perception of the goods or services offered. The brand image of hotel industry is independent of traveler's market, that's why hotel image is placed as an important factor among customer loyalty (Heung et al., 1996). For this reason, this point to that good image directed to customer satisfaction and unfavorable image leads to dissatisfaction.

The rationale of this study is to look at the association between services quality of Pakistani hotel and to scrutinize cause on customer satisfaction, brand image and customer loyalty. The hotel industry is the fast growing sector all around the globe and few years before nobody paid much attention to conduct research on this sector. For this reason, we investigate the service quality of business in Pakistan.

The significant of this research is that very few studies have been conducted on this sector and service quality is the major part for hotel industry. This study will help both academia and practitioner because academia can use this study result to augment their results and for future research consideration, while practitioners may use this study to boost up their profitability by implementing new strategies to those areas in which they are lacking.

\section{Literature Review}

In this cut throttle competition, every company wants to get edge over other. For hotel industry, service quality is an important consideration, so companies striving to attain maximum customer satisfaction by providing quality services. According to Min \& Min (1996) service quality is the life blood for hotel industry and service quality is further linked with customer satisfaction being studied by Shi \& Su, (2007) and the other one, customer satisfaction is related with customer loyalty (Han, Barrett \& Back, 2009). Service quality is 
considered an evaluation between service prospect and what actually has been received (Parasuraman et, al., 1985).

Zeithamlet, al. (1985) conducted a study in which they presented the ten useful requirements to measure the quality of services provided to the customers. These are: responsiveness, reliability, tangibility, credibility, communication, security, competence, understanding the customers, courtesy and service accessibility. In 1990, Zeithamlet, al. presented the five dimensional SERVQUAL scale to measure the service quality. These dimensions are: responsiveness, reliability, assurance, tangibility and empathy. These constructs have higher correlation with each other.

Narangaja vancaet, al. (2008) presented a study in which they explored that hotel performance is unswervingly related to service quality. They concluded that higher service quality can be maintained due to change in hotel performance. They provided the four aspects to improve service quality those were: hotel employees, service delivery, prestige and guest facilities and surroundings. Hope and Wild (1994) argued that high level of tools are used to satisfy the customers regarding service quality. This all happens when the managers are efficient, but unfortunately this is the great problem with hotel managers to captivate the customers (Shi \& Su, 2007). According to Petkova et, al. (2000) service quality is the key ingredient for every customer and customer is the key person who describes the quality (Berry et,al., 1993). To provide the good quality services to the customers, hotel managers should understand the expectations of their customers (Nilsson, Johnson \&Gustaffson, 2001; Shi $\& \mathrm{Su}, 2007)$.

\section{Customer Satisfaction}

Customer satisfaction is the internal feelings of every individual which may be satisfaction or dissatisfaction resulting from the assessment of services provided to an individual in context to customer's anticipation by an organization (Oliver, 1980; Leisen\& Vance, 2001). Service provides are continuously trying to improve the service just to satisfy their customer because higher customer satisfaction will leads towards customer loyalty (Lokeet, al., 2011).

The most important concept of customer satisfaction is accepted all around the world is the expectancy disconfirmation theory (Barsky, 1992). This theory was presented by Oliver in 1980, he presented that satisfaction stage is the resultant of distinction between anticipated and supposed performance. Satisfaction will be encouraging when the actual level of services or products is better than the anticipated (positive disconfirmation), whereas (negative disconfirmation) when the product or services level is lower than expected (Oliver, 1980).

Gilbert and Horsnell (1998) explored in their research that hotel industry determine the customer satisfaction through gust comment cards (GCCs). These cards are usually distributed in hotel reception desks, rooms and other visible places. Some researches show that evaluation process of customer satisfaction is inadequate (Barsky, 1992) some common errors can be sample quality, data collection and analysis and design of GCCs (Gilbert \&Horsnell, 1992). These errors can be improve by giving questionnaire to the hotel guests and give them incentives for completion of the questionnaires. These questionnaires are based on disconfirmation pattern and value expectancy theory. Through this way the analysis will be very accurate because it will provide a true picture that the customer's satisfaction is below their expectations or above (Holjevac, Markovic \& Raspor, 2013).

\section{Customer Loyalty}

Kandampully and Suhartanto (2000) explained the customer loyalty in their research that "customer who repurchases from the same service provider whenever possible and who continues to recommend or maintains a positive attitude towards the service provider."Julander et al. (1997) explained that customer loyalty has two magnitude: the first one is behavioral and the other is attitudinal. The behavior loyalty means the customer is intend to repurchase the brand or services from the service provider over time (Bowen \& Shoemaker, 1998), whereas, attitudinal loyalty means the customer intend to repurchase and also recommend other which is the good sign of customer loyalty (Getty \& Thompson, 1994).

Some empirical researches suggest that there is strong activist relationship between customer satisfaction and the most important variable that is customer loyalty (Zeithaml et al., 1996). Moreover, service quality studies ( Brodie et al., 2009) proposed that higher service quality will leads towards higher and positive customer repurchase behavior.

\section{Brand Image}

The brand is one of the important assets of the company. Brand image is explained by Keller (1993, pp.3) that "brand is reflected by the brand links held by in consumer memory". In simple words brand image is basically what comes into the consumers mind when brand placed in front of him. Consequently, these associations are building up into the consumers mind from the direct experience of service they have, after those 
experiences they make conclusion by contrasting their previous experiences with the company and the set associations (Martinez \&Pina, 2003).

There are many empirical evidences that proved that customer loyalty and brand image have positive correlation with each other (Selnes, 1993; Zins, 2001). Whereas, other researches proved positive contact on brand image by that service quality (Brodie et al., 2009) and customer satisfaction comprise positive relationship with brand image. Another study found that image is positively related with customer satisfaction and customer preference in lavishness hotels. This showed that pleasing image leads towards customer preferences and customer satisfaction whereas, unpleasing image can leads towards customer dissatisfaction (Mazanec, 1995).

\section{Hypothesis Generation:}

Hypothesis 1: Service quality has a direct and significant effect on customer satisfaction.

Hypothesis 2: Customer satisfaction has a direct and significant effect on customer loyalty.

Hypothesis 3: Service quality has a direct and significant effect on customer loyalty.

Hypothesis 4: Customer loyalty has a direct and significant effect on brand image.

Hypothesis 5: Service quality has a direct and significant effect on brand image.

Hypothesis 6: Customer satisfaction has a direct and significant effect on brand image.

\section{Methodology}

This study investigates the impact of service quality on customer satisfaction, customer loyalty and brand image of the hotel industry of Pakistan. For this purpose, customer's experience was accumulated. Quantitative data was collected to gather the responses of the customers through questionnaires. Each variable has its own set of questions which measure it and the questionnaire was used by Krit and $\mathrm{Li}$ (2012).

\section{Sample:}

The study was conducted on Hotel industry of Pakistan and sample size of the study was 8 ( 3 and 5 star) hotels, located in different cities of Pakistan. Random sampling technique was used to gather the data. We have distributed 250 questionnaires among the customers and response rate was approximately $86 \%$. The questionnaire was filled by the customers and requested them to fill it properly.

\section{Research Instrument:}

There are four variables in this study and each of them has separate set of questions. There are 52 questions that were used to measure the variables of the above study. Questionnaire was constructed on 5 points Likert scale where $1=$ strongly disagree, $2=$ disagree, $3=$ neutral, $4=$ agree and $5=$ strongly agree.

\section{Statistical Tool:}

The tool that was used to measure the quantitative data is SPSS 19. The collected data was then analyzed through Structural equation modeling (SEM) technique.

\section{Discussion and Analysis}

The data is collected from the customers of the hotels in Pakistan (Table 1). The primary data is used for the further analysis.

Table 1

\begin{tabular}{|l|l|l|l|}
\hline Hotels & Sent & Return & Response Rate \\
\hline $\begin{array}{l}\text { Pearl Continental Islamabad } \\
\text { hotel }\end{array}$ & 30 & 27 & $90 \%$ \\
\hline Serena Islamabad & 30 & 25 & $83 \%$ \\
\hline PC Bhurban & 30 & 29 & $97 \%$ \\
\hline PC Peshawar & 30 & 24 & $80 \%$ \\
\hline Serena Faisalabad & 30 & 26 & $86.6 \%$ \\
\hline Marriott Lahore & 30 & 24 & $80 \%$ \\
\hline Sheraton Karachi Hotel & 40 & 36 & $90 \%$ \\
\hline Hotel Ambassador Lahore & 30 & 25 & $83.4 \%$ \\
\hline
\end{tabular}

To check the impact of variables on one another SEM was run. For the above purpose the structural equation model were established. The six hypotheses were tested after evaluating the path coefficients and then the significance levels among the required paths in the model. 
The Impact Of Service Quality On Customer Satisfaction, Customer Loyalty And Brand Image:

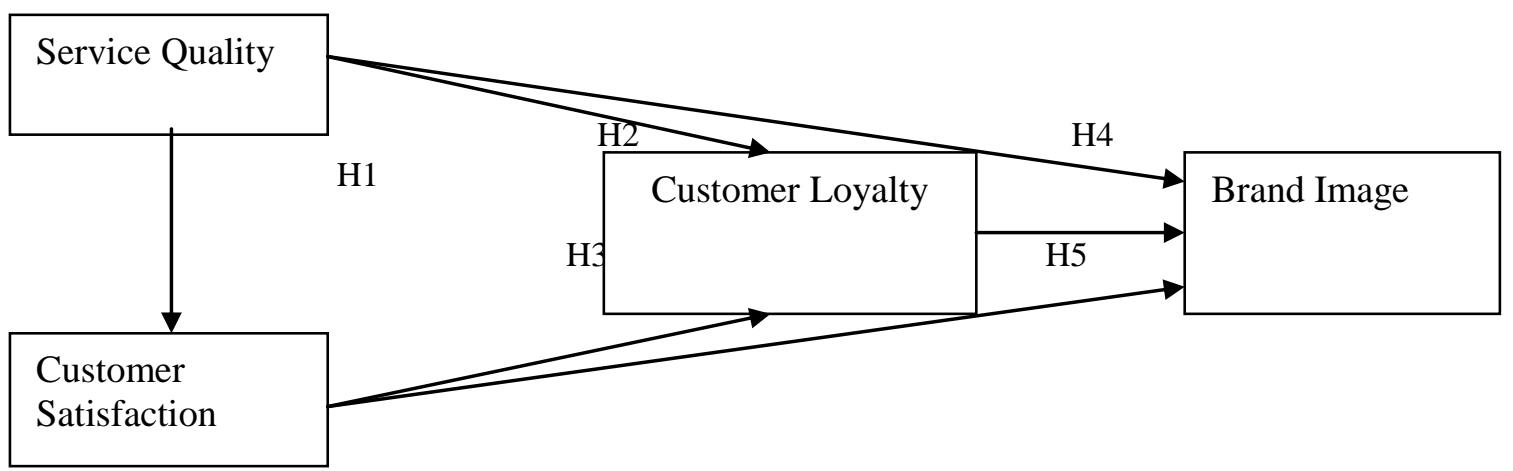

Figure 1. Framework/The brief model

The analysis of the SEM showed that there is positive and significant relationship between the service quality and the customer satisfaction with $0.250 *$ and $\mathrm{t}=5.037, \mathrm{p}<0.01, \mathrm{R} 2=0.070$, hence $\mathrm{H} 1$ accepted. The results indicated that if the hotels improved the service quality the graph of customer satisfaction will also increase. The results further confirm the study of Qin et al., (2010). The H2 was the verified by checking the relationship between the service quality and customer loyalty. They have significant and positive consequence with a significance level with $0.478 *, \mathrm{t}=6.037, \mathrm{p}<0.01, \mathrm{R} 2=0.57$. The increased quality made the customers to remain attached with the hotels or remain loyal with it (Table 2).

Customer satisfaction also have a significant impact on customer loyalty $(0.284 *)$ as shown by the results as $\mathrm{t}=8.037, \mathrm{p}<0.01, \mathrm{R} 2=0.560$. So this leads towards the acceptance of H3.The findings supported the study of Williams and Naumann (2011). The satisfied customer prefers to be loyal as well. The highly satisfied customers become the loyal customers as well. The results matched with Torres and Tribo, (2010).

In testing the straight relationship of service quality and brand image postulated in $\mathrm{H} 4$ it found this relationship as significant having $0.217 *, \mathrm{t}=9.15, \mathrm{p}=0.000, \mathrm{R} 2=0.32$ ) therefore $\mathrm{H} 4$ also accepted. Furthermore, in $\mathrm{H} 5$ the positive relationship between customer satisfaction and brand image was expected $(0.314 * *)$, it also revealed a significant relationship $\mathrm{t}=8.7, \mathrm{p}=0.000, \mathrm{R} 2=0.541$ ).

The last hypotheses $\mathrm{H} 6$ was also accepted showing the significant relationship between the customer loyalty and brand image $(0.444 * *)$ having values of $\mathrm{t}=10.15, \mathrm{p}=0.000, \mathrm{R} 2=0.62)$.

\section{Table 2}

\begin{tabular}{|l|l|}
\hline The relationships between variables & Standardized regression weights \\
\hline $\begin{array}{l}\text { Service Quality Customer } \\
\text { Satisfaction }\end{array}$ & $0.250 *$ \\
\hline Service Quality Customer Loyalty & $0.478 *$ \\
\hline Customer Satisfaction CustomerLoyalty & $0.284 *$ \\
\hline Service Quality Brandmage & $0.217 *$ \\
\hline Customer Satisfaction Brand Image & $0.314 * *$ \\
\hline Customer Loyalty Brand & $0.444 * *$ \\
\hline
\end{tabular}

\section{Conclusion}

The study was conducted to understand the relationship between service quality, customer satisfaction with customer loyalty and brand image in all the directions. All the hypotheses were accepted and it proved from the analysis. The service quality and customer satisfaction is directly related as high quality enhances the satisfaction at the same time. The innovation in service quality or by improving the quality of service the hotels become more able to satisfy the customers. The satisfaction of customer leads toward loyalty as shown by the above study. Customers when felt satisfied, they remain loyal with the hotel and hence it affects the purchasing behavior. 
The service quality of the hotels also enhanced the loyalty of the customers. The results also matched with the Brodie et al., (2009). Moreover, the customer loyalty and service quality is also significantly related with brand image. The loyalty of the customer increases their perception of the brand image.

All the service oriented business specially the hotel industry focused on the service quality as it increases the customer satisfaction and the loyalty and brand image. The enhancement in the service quality comes from different ways by considering the convenience of the customers. The customer satisfaction is basically the objective of the hotels which make them to give maximum attention. The hotels focused on creating the clear image for the customers by attracting them by increasing the comfort level. These all paths help the business to flourish and also have a tremendous impact on the profitability of the organization.

Pakistan being the underdeveloped country needs to invest in the hotel industry. The growth of hotel industry impacts the economy as well. So for increasing the standards of life styles the service quality should be improved which will increase the customer satisfaction and brand loyal.

\section{Recommendations and Suggestions}

The finding of the above study helps the hotel industry to focus more on the research progress to increase the service quality and customer satisfaction by considering it as the hotel management objective. Moreover, the results help the academia to understand the variables which increase the brand loyalty. For further study the larger sample size should be considered to understand the variety of customer's perception and attitudes.

\section{Reference}

[1]. Barsky, J.D. (1992), “Customer Satisfaction in the Hotel Industry: Meaning and Measurement”. Hospitality Research Journal, Vol. 16(1), pp. 51-73.

[2]. Berry, L.L., Parasuraman, A., Zeithaml, V.A., Adsit, D., Hater, J., Vanetti, E.J. and Veale, D.J. (1993), "Improving Service Quality in America: Lessons Learned". Academy of Management Executive, Vol. 8(2), pp. 32-52.

[3]. Bowen, J. and Shoemaker, S. (1998), "Loyalty: a strategic commitment”, Cornell H.R.A. Quarterly , Vol. 2, pp. 12-25.

[4]. Brodie, R. J., Whittome, J. R. M., and Brush, G. J. (2009), "Investigating the service brand: A customer value perspective". Journal of Business Research, Vol.62, pp. 345-355. http://dx.doi.org/10.1016/j.jbusres.2008.06.008

[5]. Getty, J.M. and Thompson, K.N. (1994), "The relationship between quality, satisfaction, and recommending behavior in lodging decision". Journal of Hospitality \& Leisure Marketing, Vol. 2(3). pp. 3-22.

[6]. Gilbert, D. \&Horsnell, S. (1998), "Customer satisfaction measurement practices in United Kingdom hotels". Journal of Hospitality \& Tourism Research, Vol. 22(4), pp. 450-464.

[7]. Gundersen, M. G., Heide, M. \& Olsson, U. H. (1996), "Hotel Guest satisfaction among Business Travellers: What Are the Important Factors?" The Cornell Hotel and Restaurant Administration Quarterly, 37(2): 72-81

[8]. Han, H., Back, K. \& Barrett, B. (2009), "Influencing factors on restaurant customers' revisit intention: The roles of emotions and switching barriers". International Journal of Hospitality Management, Vol. 28, pp. 563-572.

[9]. Heung, V.C.S., Mok, C. and Kwan, A. (1996), "Brand loyalty in hotels: an exploratory study of overseas visitors to Hong Kong". Australian Journal of Hospitality Management, Vol. 3 No.1, pp.1-11.

[10]. Holjevac, I.A., Markovic, S. \&Raspor,S. (2013), "customer satisfaction measurement in hotel industry: Content analysis study". http://bib.irb.hr/datoteka/397335.PAP039.pdf.

[11]. Hope, B.G., and Wild, R.H. (1994), “An Expert Support System for Service Quality Improvement”, IEEE.

[12]. Kandampully, J. and Suhartanto, D. (2000), "Customer loyalty in the hotel industry: the role of customer satisfaction and image". International journal of contemporary hospitality management, Vol. 12(6), pp. 346-351.

[13]. Keller, K. L. (1993), “Conceptualizing, measuring and managing customer-based brand equity”. Journal of Marketing, Vol.57(1), pp. 1-22. http://dx.doi.org/10.2307/1252054.

[14]. Leisen, B. and Vance, C. (2001), “Cross-national Assessment of Service Quality in Telecommunication”. Journal of Marketing. Vol. 11(5), pp.307-317.

[15]. Loke, S.P., Taiwo, A.A., Salim, H.M. and Downe, A.G. (2011), "Service Quality and Customer Satisfaction in a Telecommunication Service Provider". International Conference on Financial Management and Economics, Vol. 11, IACSIT Press, Singapore.

[16]. Martinez, E., \&Pina. J. (2003), "The negative impact of brand extensions on parent brand image". Journal of product \& brand management,Vol.12(7),pp. 432-448. http://dx.doi.org/10.1108/10610420310506001

[17]. Mazanec, J.A. (1995), "Positioning analysis with self-organizing maps: an exploratory study on luxury hotels". Cornell H.R..A Quarterly, Vol. 12, pp. 80-92.

[18]. Min, H. \& Min, H. (1996), "Benchmarking the quality of hotel services: managerial perspectives". International Journal of Quality \& Reliability Management, Vol. 14 No. 6, 1997, pp. 582-597.

[19]. Narangajavana, Y. and Hu, B. (2008), "The Relationship between the Hotel Rating System, Service Quality Improvement, and Hotel Performance Changes: A Canonical Analysis of Hotels in Thailand". Journal of Quality Assurance in Hospitality \& Tourism, Vol. 9(1), pp. $34-56$

[20]. Nilsson, L., Johnson, M.D. and Gustafsson, A. (2001). "The impact of quality practices on customer satisfaction and business results: product versus service organizations". Journal of Quality Management, Vol. 6, pp. 5-27.

[21]. Oliver, R. L. (1980), "A cognitive model of the antecedents and consequences of satisfaction decisions". Journal of Marketing Research. Vol. 17, pp. 460-469.

[22]. Palmer, A., Beggs, R., and Caroline, K-M. (2000), "Equity and repurchase intention following service failure". Journal of Services Marketing, Vol. 6(6), pp. 513-528. http://dx.doi.org/10.1108/08876040010347624

[23]. Parasuraman, A., Zeithaml, V. A., \& Berry, L. L. (1985), "A conceptual model of service quality and its implications for future research". Journal of Marketing, Vol. 49(4), pp. 41-50. http://dx.doi.org/10.2307/1251430

[24]. Petkova, V.T., Sander, P.C. and Brombacher, A.C. (2000), "The use of quality metrics in service centres". International Journal Production Economics. Vol. 67, pp. 27-36 
[25]. Qin, H., Prybutok, V. R., \& Zhao, Q. (2010). Perceived service quality in fast-food restaurants: empirical evidencefrom China. International Journal of Quality \& Reliability Management, 27(4), 424-437.http://dx.doi.org/10.1108/02656711011035129

[26]. Selnes, F. (1993), "An examination of the effect of product performance on brand reputation, satisfaction and loyalty". European Journal of Marketing, Vol. 27(9), pp.19-35. http://dx.doi.org/10.1108/03090569310043179

[27]. Shi, J. \& Su, Q. (2007), "Evaluation of Hotel Service Quality Based on Customer Satisfaction". IEEE.

[28]. Torres, A., \&Tribó, J. A. (2010). Customer satisfaction and brand equity. Journal of Business Research, 64(10),1089-1096. http://dx.doi.org/10.1016/j.jbusres.2010.12.001

[29]. Williams, P., \&Naumann, E. (2011). Customer satisfaction and business performance: a firm-level analysis. Journalof Services Marketing, (25/1), 20-32. http://dx.doi.org/10.1108/08876041111107032

[30]. Zeithaml, V.A., Parasuraman, A. and Berry, L.L. (1990), "Delivering quality service: Balancing customer perceptions and expectations". New York: The Free Press.

[31]. Zins, A. H. (2001), "Relative attitudes and commitment in customer loyalty models: Some experiences in the commercial airline industry". International Journal of Service Industry Management, Vol.12(3/4), pp. 269-294. http://dx.doi.org/10.1108/EUM0000000005521

[32]. Zeithaml, V.A. and Bitner, M.J. (1996), "Services marketing”, McGraw-Hill International Editions, New York, NY. 